\title{
GURRUMINOS, PETIMETRES, ABATES Y CURRUTACOS EN EL TEATRO BREVE DEL SIGLO XVIII
}

\author{
Josep Maria SALA VALldaura \\ Universitat de Lleida
}

\section{RESUMEN}

El estudio de ciertos modelos negativos del teatro breve del siglo XVIII revela no sólo la continuidad cómica de los tipos, sino también su relación con los ideales de conducta coetáneos: la autoridad del marido, la discreción de la mujer, el cuidado de la economía familiar... Los sainetes se unen a otros géneros literarios (el periodismo, la poesía satírica y el ensayo de carácter moral) en la ridiculización de quienes practican el cortejo y aplauden nuevas formas de sociabilidad, las modas y los bailes extranjeros, etc. frente a la conducta y los gustos tradicionales. Ejemplos tomados de Antonio de Zamora, Agramont, Ramón de la Cruz, Vázquez y González del Castillo sirven para argumentar tales reticencias ante el cambio de mentalidades de una nueva cultura del ocio, así como para observarlo a contrario: su "afeminación", su frivolidad y su inutilidad.

Palabras clave: Teatro breve del siglo XVIII, petimetría y majismo, homosexualidad, Antonio de Zamora, Juan de Agramont y Toledo, Ramón de la Cruz, Juan Ignacio González del Castillo.

\section{GURRUMINOS, PETIMETRES, ABATES AND CURRUTACOS IN 18TH CENTURY SAINETES}

\section{ABSTRACT}

This study of certain negative models of sainetes [afterpieces] from the $18^{\text {th }}$ century reveals not only a continuity of comic stereotypes, but also their relationship to the ideals of behavior of the era: the authority of the husband, the submissiveness of the wife, thriftiness in managing household finances, etc. Afterpieces join other literary genres (journalism, satirical poetry and the moral essay) in ridiculing those who are involved in the practice of cortejo and who readily adopt new forms of social behavior, fashions, foreign dances, etc., in contrast to traditional ways and tastes. Examples taken from Antonio de Zamora, Agramont, Ramón de la Cruz, Vázquez and González del Castillo are used to illustrate this reticence towards changes in mentality of a new culture of leisure, as well as to observe it a contrario: its "feminization", its frivolity, and its uselessness.

Key words: Sainetes (Afterpieces) from the 18th century, Petimetría and majismo, Homosexuality, Antonio de Zamora, Juan de Agramont y Toledo, Ramón de la Cruz, Juan Ignacio González del Castillo. 


\section{LA VIDA DEL TEATRO}

En el fin de fiesta La comedia casera, segunda parte (1766), de Ramón de la Cruz, se lee o escucha este diálogo:

$\begin{array}{ll}\text { BLAS. } & \text { Señor don Blas, ¿de qué libro } \\ & \text { ha sacado usté ese texto? } \\ \text { ChINICA. } & \text { Del teatro de la vida } \\ & \text { humana, que es donde } l e o^{1} .\end{array}$

Cruz no mentía, por supuesto, porque pregunta y respuesta se referían a algo tan propio de la vida diaria de ciertos sectores sociales como el cortejo. Pero el teatro de la vida encontraba el cauce jocoso en la vida del teatro, porque era igualmente cierto que el público se reía desde hacía siglos de una serie de diálogos, acciones y situaciones en torno a la mujer, el amor y el matrimonio. Malcasadas o busconas, tutores y maridos burlados o pretendientes con toda clase de ridiculeces y defectos desfilaban pieza tras pieza para demostrar, con cierta dosis de crueldad, cómo la naturaleza se abre paso entre fingimientos e intereses nunca o casi nunca verdaderamente sentimentales. Cabe asociar toda esta secular retórica de la risa con la degradación con que el teatro breve, desde un hipotético y consensuado eje de la normalidad, escarnece a quienes se singularizan y se apartan del común:

Mediante la parodia y la caricatura todos los objetos (lo escatológico y lo obsceno, pero también el honor, el valor, la lealtad, el patriotismo...) y sujetos (pícaros y rufianes, marcas y celestinas, pero también nobles, príncipes, reyes, héroes...) son posibles soportes de la risa y la burla ${ }^{2}$.

En última instancia, la burla alcanzará a cada grupo social, a las mujeres y a los hombres, a viejos y jóvenes, a pobres y ricos, porque todos pueden presentar torpezas morales y defectos físicos y para que todos puedan reír de sí mismos y de los demás.

No hace falta que ese proceso degradador sea totalmente inversor y subversivo, basta casi siempre con algún grado de transgresión. La permisibilidad social e institucional regulará el género en que cabe o no degradar al rey, al militar, al médico, al cura, al boticario, al juez, al sacristán, etc., pues es evidente que hay una literatura, la dramática comercial, con unas cortapisas mayores que otras de transmisión oral. Por ejemplo, la fi-

${ }^{1}$ Sainetes de... en su mayoría inéditos. Cotarelo y Mori, E. (ed). Madrid: Bailley Bailliere, 1915, N.B.A.E., 23, I, p. 290 a.

${ }^{2}$ ARELLANO, Ignacio. «Las máscaras de Demócrito: en torno a la risa en el Siglo de Oro». En Arellano, I. y Roncero, V. (eds.). Demócrito áureo. Los códigos de la risa en el Siglo de Oro. Sevilla: Renacimiento, 2006, pp. 329-359; la cita en pp. 353-354. 
gura del gracioso da lugar al teatro breve y crece con él precisamente para poder abrir y mantener un paréntesis amoral que, de otro modo, hubiera quedado obliterado en las representaciones teatrales siempre más graves, regidas forzosamente por principios censoriales siempre más estrictos. Desde este punto de vista estético y ético, los intermedios son excursos carentes de corrección en un desarrollo mucho más concatenado y educado.

La mueca de Talía afea la realidad, porque, desde mucho antes del Barroco, jamás el ser se muestra en el parecer. Ante los ojos moralmente superiores del público que los juzga y se ríe, los tipos simulan el amor o la valentía y revelan la gran diferencia que separa su falso estar teatral y teatralizado de su verdadero ser. Sin que llegue a suponer cambios radicales o genéricos, a lo largo de los siglos XVI y XVII hay una cierta evolución de los tipos entremesiles, porque la vida del teatro exige mucha redundancia y algún que otro cambio adecuado al teatro de la vida. En palabras de María José Martínez López,

\begin{abstract}
los personajes femeninos se perfilan según una doble pauta, la del erotismo y la del afán de bienes materiales. Estos dos elementos constituyen el punto de arranque de su actuación. Los tipos tradicionales femeninos se perfilan, de modo paralelo a los tipos masculinos, en función del erotismo. Sin embargo, la malcasada, tipo tradicional por excelencia, lo hace también con respecto al matrimonio, causa de todos sus desvíos. Así, su definición lleva implícita la del marido cornudo, manso y consentido. La figura moderna [la del XVII] también guarda relación con el matrimonio, pero como medio para conseguir un estatus sociodramático superior. Las figuras modernas, tanto en la versión masculina como en la femenina, se deslindan con respecto a una dimensión sociodramática. La comicidad de los dos grupos se fundamenta en la inadaptación o sobreadecuación que manifiestan con respecto a lo que creen ser o a lo que desean parecer. En el caso de la figura femenina el galanteo se supedita al afán de nobleza y de bienes materiales. En cuanto a la figura masculina la inadecuación se manifiesta con respecto a valores superiores, como los de la valentía o de la nobleza. La incapacidad de ajustarse a lo que son realmente hace de las figuras masculinas personajes ridículos, objeto seguro de las burlas de las damas ${ }^{3}$.
\end{abstract}

La degradación del honor pasa, obviamente, por perderlo: de ahí la deshonra en el caso del esposo y la esposa por el adulterio más o menos sugerido $^{4}$; la cobardía, en el caso del héroe (quizás eufemística y litóticamente reducido a un soldado fanfarrón); la pedantería ignorante, en el caso del sabio (en la figura del médico, por ejemplo, convertido en funcionario de la muerte); la lascivia, en quien debería ser modelo de casta religiosi-

${ }^{3}$ El entremés, radiografía de un género. Toulouse: Presses Universitaires du Mirail, 1997, pp. 149-150.

${ }^{4}$ Remito, para una síntesis suficiente sobre los entremeses de burlas amatorias, a HUERTA CALVO, Javier. El nuevo mundo de la risa. Estudios sobre el teatro breve y la comicidad en los Siglos de Oro. Palma de Mallorca: José J. de Olañeta ed., 1995, cap. III, pp. 67-91. 
dad (valga el sacristán si el sacerdote queda censorialmente a salvo), o la simpleza, de quien no conoce los principios de la urbanidad.

Por esto, si un payo aparece con su pollino en un decorado urbano, la animalización de aquél tenderá a igualarlos. Del mismo modo, la presencia de un personaje de clase alta con una indumentaria extravagante descalifica irrisoriamente todo lo que dice y hace. Así, el burro y el vestido se convierten en marcas visuales de función degradadora equivalente. En puridad, las palabras, los tonos, la indumentaria, los gestos, los movimientos, todo el lenguaje verbal y corporal del actor traduce un proceso de perversión degradador, animalizador y cosificador. No en vano el afeminado y jorobado Cosme Pérez, "Juan Rana", protagonizó tantos éxitos del teatro breve, y no en vano resulta frecuente una breve acotación de alta eficacia cómica: sale "ridículo" o "de figurón ridículo". El afeminamiento, también como una forma de ridiculez y de extravagancia, formaba parte de las estrategias graciosas, presentes en la cultura farsesca y detectables, por ejemplo, en la apariencia con que Mostrenco sale a escena en Pedro de Urdemalas, de Cervantes ${ }^{5}$, que Evangelina Rodríguez Cuadros apostilla de esta manera:

Los espectadores habrían de ver a Mostrenco en la guisa ridícula de ir tocada la cabeza con bufos o bollos, cubriendo las orejas, con trajes bicolor verde y amarillo, arrastrando cascabeles, con un jubón corto, lo que, junto con los papos, afeminaría burlescamente su apariencia y tocando el tambor ${ }^{6}$.

\section{EL TEATRO DE LA VIDA}

Sin detrimento de la herencia cómica de las escenas de los graciosos - comedias de figurón y entremeses, sobre todo-, el acercamiento a la cotidianidad y a la intimidad que algunos llaman con razón mímesis costumbrista implica la existencia de una base real. Especialmente en la segunda mitad del siglo XVIII, los viajeros reflejan que en las calles españolas se cruzan y se detienen majos y petimetres, manolas y madamas. Unas y otros se contonean, charlan y exhiben sus galas, con una eclosión de vestidos, peinados, ademanes y gestos jamás vista hasta entonces. Los viajeros prestan atención a los sectores sociales que más fácilmente se hacen notar; por ejemplo, en dos extremos opuestos, las troteras y los exquisitos. Así, pues, leemos sobre las prostitutas:

${ }^{5}$ Obra de fácil lectura en la segunda mitad del siglo XVIII, a raíz de la edición de Blas Nasarre, Comedias y entremeses, con una Dissertacion o prologo sobre las Comedias de España. Madrid: Imprenta de Antonio Marín, 1749, 2 vols.

${ }^{6}$ La técnica del actor español en el Barroco. Hipótesis y documentos. Madrid: Castalia, 1998, p. 186. (Respeto la cursiva del texto original.) 
Dès que la nuit commence, douze à quinze cents catins s'emparent des rues et des promenades de Madrid.

Teint brun, jolis pieds, petit front, cheveux noirs, grands yeux, nez de chiffon, grande bouche bien bordée, bien blanche, bien coupée, bien rose, joli soin de voix, vous séduit; vous succombez; vous montez, et vous sortez, dit-on, malade ${ }^{7}$.

Y sobre los elegantes:

on trouve ici, comme dans le reste du monde, des élégants, des hommes agréables, qui, comme leurs confrères de-delà les monts, ont des chiens, des jockets, des chevaux, des dettes, des talons rouges, de grands chapeaux, les épaules rondes et la vue basse.

La visibilidad de los cambios pasa también por la aceptación de costumbres en las ciudades españolas que los viajeros extranjeros conocen de sus países, y que a veces les sorprenden por los cambios sufridos en la transculturalización o por el contraste con las conductas tradicionales españolas. La moda de una nueva coquetería y otras maneras de relacionarse ellos y ellas atravesaron los Alpes y los Pirineos, lo que servirá para que el teatro vivifique la risa gramaticalizada con nuevos sujetos y objetos graciosos. El petimetre que protagonizó muchas sátiras en la Francia de finales del siglo XVII y comienzos del Dieciocho no es exactamente el mismo que zaherirá la literatura dramática castellana:

Les petits-maîtres échappèrent aux mémorialistes pour devenir un sujet commun aux satiriques, aux moralistes, aux auteurs comiques, aux jounalistes, enfin aux romanciers. Entre 1690 et 1700 , on nous les présente à l'envi insolents dans les sociétés, rossant le guet, malmenant les clients des cafés, importuns au thêatre, buvant, jouant, jurant toujours, souvenir de leurs origines, «sans estime pour le sexe» ${ }^{8}$.

La propia comicidad requiere un conocimiento compartido por parte de autor, obra y público, y si bien los literatos españoles aprenden en Molière o en Goldoni la vida del teatro y la comedia humana, miran el espejo de la sociedad coetánea y lo convierten en cóncavo al escribir sus entremeses y sainetes. Entre los procedimientos para hacer reír figura, pues,

la burla de modelos interpretativos. Esta manera es más elaborada, por cuanto necesita de un referente conocido por todos los que participan en el acto comunicativo de la representación, a la vez que es necesaria una común forma (negativa) de entender esa manera de la que se hace mofa9

${ }^{7}$ LANGLE, Fleuriot de. Voyage de Figaro en Espagne. Favre, Robert (ed.). SaintÉtienne: Université de Saint-Étienne, 1991, p. 35; la cita que sigue, p. 57.

${ }^{8}$ DELOFFRE, Frédéric. «Notice». En: MARIVAUX. Le Petit-Maître corrigé. Thêatre complet. París: Bordas, 1992, II pp. 145-149; la cita en p. 147.

9 ÁLVAREZ BARRIENTOS, Joaquín. «Risa e 'ilusión' escénica. Más sobre el actor en el siglo XVIII». Risas y sonrisas en el teatro de los siglos XVIII y XIX. Scriptura, 1999, 15, pp. 29-50; la cita en p. 30. 
Los libros de viajes y, en general, la literatura documentan simultánea y paralelamente lo que los autores teatrales ingenian para las tablas con una interesada distorsión burlesca. Por el lado lingüístico, también ciertos neologismos y la ampliación de algunas definiciones atestiguan la existencia de nuevas costumbres en los paseos y salones dieciochescos. Así, el término "gurrumino" - "el marido que obedece indebidamente y contempla con exceso a su mujer"- era voz reciente para el Diccionario de Autoridades (1726), que también define "abate", "chichisveo", "cortejo", "madama", "petimetre", a veces valorando y juzgando negativamente sus referentes:

- "abate", "palabra italiana introducida modernamente para denotar al que anda vestido con cuello clerical, casaca y capa corta";

- "chichisveo", «especie de galanteo, obsequio y servicio cortesano de un hombre a una mujer, que no reprehende el empacho, pero le condena por peligroso la conciencia»;

- "cortejo", «asistencia y acompañamiento obsequioso que se hace a otro»y, también, «agasajo y regalo que se hace a otro»;

- "madama", «voz francesa y título de honor que vale lo mismo que señora [...] Hoy lo usan algunos en el trato cortesano con las mujeres»; y

— "petimetre", «el joven que cuida demasiadamente de su compostura y de seguir las modas» ${ }^{10}$.

Mario Damonte dice que el término "cicisbeo", con esta grafía, entró en España en 1717 y aporta citas de un rechazo casi inmediato en sendos poemas satíricos de Gerardo Lobo y Francisco Benegassi... ${ }^{11}$ Con el italianismo había entrado la costumbre.

Para insistir y precisar: esos viajeros que se asombran de la vitalidad diurna y nocturna de las calles españolas sancionan el cambio, un cambio que suponía una nueva cultura del ocio, con la que los más adinerados en España empezaban a disfrutar su pujanza comercial y mercanti1 ${ }^{12}$. Los li-

${ }^{10}$ Utilizo la edición facsímil: Madrid: Gredos, 2002, 3 vols.

11 «Cicisbeo secondo Gerardo Lobo e Francisco Benegassi: un italianismo nella vita sociale e mondana della Spagna del primo Settecento». En: CALDERONE, A. (ed.). De místicos y mágicos, clásicos y románticos. Messina: Armando Siciliano Ed., 1993, pp. 201208. (Quizás no resultaba tan necesario, pero "sigisbé" o "sigisbée" no se documenta en Francia sino en 1765 y "cicisbeo" en Alemania, hasta 1784; ibid., p. 201).

${ }^{12} \mathrm{El}$ auge de los estudios sobre la historia de la cultura y de las mentalidades ha proporcionado ya un buen número de aproximaciones bibliográficas a las nuevas formas de sociabilidad del Dieciocho. Remito, para una visión general, a CRAVERI, Benedetta. La cultura de la conversación. Palma, César (trad.). Madrid: Siruela, 2003, y para la sociedad española, LORENZO ÁLVAREZ, Elena de. «La sociabilidad ilustrada: instinto de conservación, 
bros, cartas y apuntaciones del turismo intelectual dan fe de lo que ocurre... y de lo que otros géneros literarios reflejan desde sus particulares espejos y lentes. En efecto, con premisas axiológicas compartidas, los artículos y ensayos morales se adelantarán en treinta años al teatro breve en el rechazo de madamas y petimetres: El chichisbeo impugnado es de 1729, y en él se lee: «Los hombres que, por el traje español se hacían más respetuosos y venerables, están hoy tan afeminados que temo que alargando más las chupas un poco y las casacas, ahorren de calzón y anden con basquiña» ${ }^{13}$; la Impugnación católica y fundada a la escandalosa moda del chichisveo, introducida en la pundonorosa nación española, del Abad de Cenicero (o sea, Juan Salazar Ontivero) es de 1737, y documenta cómo desde hacía unos años los abates visitaban los estrados y tertuliaban con las madamas ${ }^{14}$. Dos años después, se editará La familia regulada, de Antonio Arbiol, que corrobora la vieja doctrina sin mencionar los nuevos usos; verbigracia, si su Marido «es disparatado, sedicioso, desamorado e ingrato, acuérdese que ya por su Matrimonio Santo es una cosa con él y que no es dueña y señora de su cuerpo, como dice el apóstol san Pablo» ${ }^{15}$.

Ensayo moral, periodismo, teatro breve... toda clase de obras se van a suceder, sobre todo a partir de la década de los sesenta, en la caricatura de la petimetría y el cortejo. En realidad, los principios morales con que se abomina de tal práctica responden a criterios secularmente empleados para denunciar el pecado y el desorden. También la dramaturgia había ya ridiculizado en la misma dirección diversos tipos, figuras o figurones: a hidalgos vestidos estrafalariamente, a lindos y a gurruminos - muestras quizás algún día para quien se atreva a escribir una historia de la comicidad basada en la homofobia-. Moreto, Cañizares y Zamora les deben una parte de su fama. La cadena, como ha señalado Mireille Coulon, es larga y prosigue en el siglo XIX: lindos, petimetres, lechuguinos, currutacos, gomosos y otros pisaverdes reúnen en sí mismos la afectación indumentaria, el afeminamiento, la frivolidad... ${ }^{16}$ Compartiendo la diana con muchos

compromiso civil y práctica social». En: CANTOS CASENAVE, M. Redes y espacios de opinión pública. Cádiz: Universidad de Cádiz, 2006, en pp. 431-444, con multitud de referencias en la nota 2.

${ }^{13}$ HARO DE SAN CLEMENTE, José. El chichisbeo impugnado... Sevilla: s. i., 1729. Apud Sánchez-Blanco, F. (ed.). El ensayo español. 2. El siglo XVIII, Barcelona: Crítica, 1997, p. 68.

${ }^{14}$ MARTÍN GAITE, Carmen. Usos amorosos del dieciocho en España. Madrid: Siglo XXI de España, 1972, p. 173.

${ }^{15}$ Zaragoza: Viuda de Joseph Mendoza, 1739, II, viii, p. 81 b; ed. facsímil: Zaragoza: Institución «Fernando el Católico». Diputación de Zaragoza, 2000.

${ }^{16}$ Vid. Le sainete à Madrid à l'époque de don Ramón de la Cruz. Pau: Publications de l’Université de Pau, 1993, esp. pp. 419-422. 
periodistas y ensayistas antiguos y modernos, los dardos que Ramón de la Cruz dirige contra el nuevo "mueble", "mono" o pisaverde apuntan a los mismos defectos y ridiculeces de aquellos sujetos irrisorios. A fines de siglo, González del Castillo los caricaturizará con la hiperteatralidad más extrema.

\section{LA NORMALIDAD MORAL}

Una y otra vez, el eje alrededor del cual se valora la conducta conyugal, la prematrimonial y la extramatrimonial expulsa fuera de su órbita cualquier comportamiento no tradicional, es decir, no arraigado en las costumbres españolas. Cabría hablar sin demasiada exageración de un miedo misoneísta y xenófobo al nuevo modelo sociomoral, al paradigma que va a caracterizar nuestra modernidad burguesa y que el cortejo inaugura. El viejo y la niña, de Leandro Fernández de Moratín, manifiesta la dificultad de ubicar el matrimonio en las nuevas formas de convivencia, pero, en líneas generales y hasta las postrimerías del siglo — cuando se abren paso las emociones de las comedias neoclásicas y el drama sentimental-, las ideas de Haro de San Clemente o de Salazar Ontivero son bastante compartidas por los literatos ilustrados, a pesar de que no las aduzcan ni las quieran citar.

Juan Sempere y Guarinos, por ejemplo, compara las relaciones matrimoniales antiguas, cuando el marido o sus parientes podían «tomarse satisfacción por sí mismo de la infidelidad y agravios de su mujer» — severidad que refrenaba «la licencia mujeril»-, con las contemporáneas: «Ahora, si un marido quiere hacer respetar su autoridad, poner orden en su casa y contener los excesos de su consorte pasa comúnmente por ridículo» ${ }^{17}$. Como puede observarse, el parecer del escritor ilustrado no difiere sustancialmente de la condena tradicionalista ante el inicio de una progresiva y muy codificada liberación de la mujeres: desde la perspectiva actual — sin embargo, poco recomendable para no caer en anacronismos-, Sempere o el periodismo de las Luces (Clavijo y Fajardo, Cañuelo, etc.) no opinan de modo muy distinto a los escritores de la literatura moral que exageran desde su puritanismo los peligros morales y económicos que el chichisveo y el cortejo representan para la sociedad española, para los matrimonios de los sectores sociales altos, la educación de sus hijos, etc.

La opinión pública a lo largo del siglo evoluciona, no podía ser de otro modo, en la consideración y la estima sociales de la mujer, que, por otra parte, continuaba siendo el centro de todas las preocupaciones morales. Cambiaban algunos criterios sobre su educación, su capacidad cultu-

${ }^{17}$ Historia del lujo y de las leyes suntuarias de España. Madrid: Imprenta Real, 1788, II, pp. 183 y 184 respectivamente; ed. facsímil: Madrid, Atlas, 1973. 
ral, etc., pero permanecía como principio compartido que «el primer deber de la mujer consistía en ser domésticas, en recluirse en el círculo de la familia, abandonando otros espacios sociales y mundanos, para dedicarse totalmente a su esposo y sus hijos» ${ }^{18}$. Para entender las diatribas contra la costumbre del cortejo practicada por las usías o madamas y los petimetres se debe partir de esta firme defensa de la familia, que imposibilitó admitir algunos beneficios culturales y económicos de la incorporación de la mujer a la vida activa, además de negar las necesidades del consumo, las ventajas de la importación comercial e incluso los beneficios morales de la sinceridad — del sí de las niñas - en las relaciones entre hombre y mujer. El ataque a los petimetres era tanto más violento cuanto más se pensaba que podía poner en peligro la armonía conyugal, la buena educación de los hijos y la economía doméstica.

El rasero de las reconvenciones, las burlas y las sátiras literarias procede de una norma moral tradicional, que, para mayor aval y garantía, se identifica con lo propio español. El ilustrado gaditano Pedro Gatell, paisano, pues, de González del Castillo compara en su periódico «las señoras españolas antiguas y las modernas» con el consiguiente panegírico de aquéllas:

\begin{abstract}
Encerradas siempre en sus casas, aplicadas a la labor, no pensaban más que en ser verdaderas esposas y madres, castas a lo sumo, sensibles por naturaleza, e ignorantes de que hubiera mayores placeres, no conocían más que sus obligaciones, ni cuidaban de otra cosa que atender a sus esposos, hijos y demás familia. Todo su esmero tenía por blanco elevar hijos para la República, los labradores y soldados. El tiempo que las restaba de sus ordinarias ocupaciones, lo empleaban con la aguja y la rueca. Por esta razón fueron tan veneradas y respetadas ${ }^{19}$.
\end{abstract}

A contrario, Manuel Antonio Ramírez de Góngora defiende el mismo modelo femenino, y de ahí esta definición por parte de una de las modernas:

Marcialidad es hablar con desenfado, tratar a todos con libertad y desechar los melindres de lo honesto, que eso de tender la ropa hasta el suelo, ocultar los semblantes de las gentes con el tapado, exprimir las palabras con el rojo pudor de la vergüenza y no presentarse a todas horas y tiempos en los paseos públicos con cuatro o cinco cortejantes, sólo se usaba en nuestras antiguas damas españolas ${ }^{20}$.

El concepto de "marcialidad" o despejo se opone al de "recato" o discreción, y su práctica exige, según acabamos de citar, la existencia de

${ }^{18}$ BOLUFER, Mónica. Mujeres e Ilustración. La construcción de la feminidad en la España del siglo XVIII. Valencia: Institució Alfons el Magnànim/Diputació de València, 1998, p. 273.

${ }^{19}$ El Argonauta español. Larriba, Elisabel (ed.). Cádiz: Universidad de Cádiz, 2003, disc. 13, p. 157.

${ }^{20}$ CADALSO, José. [En realidad, la obra es de Manuel Antonio Ramírez de Góngora]. Óptica del cortejo (con Los eruditos a la violeta). Madrid: CI-AP, s. a., $2^{\mathrm{a}}$ ed., «Sueño proemial», p. 23. 
quienes galanteen a estas mujeres, por lo general ya casadas, porque de otro modo deberían guardarse algo más para encontrar marido.

Como un moderno Diógenes, José Clavijo y Fajardo busca «adónde se han mudado los hombres», pero encuentra tan solo (a) un petimetre, es decir, «un gracioso muñeco»: «iQué bien peinado!, iy cómo camina con pasos de rigodón y de minuet! Una tienda de dijes trae colgada en cada uno de los dos relojes. ¡Cuántos galones y qué ricos encajes!». Continúa sin tener suerte y se topa luego con dos «animales tan depravados», o sea, con una pareja de cortejos, que, pese a odiarse, «se halagan, se acarician, se abrazan, se dan las manos en señal de amistad, se besan, se dicen mil lisonjas» ${ }^{21}$.

Las tentativas por parte del poder político e intelectual para hacer de las letras un canal propagador de la "normalidad" moral afectaron al teatro breve de los locales comerciales, no tanto porque terminaran marginando los entremeses de Trullo como porque fueron acercando el género a cierta coherencia causal en el desarrollo y al moralismo en los desenlaces y ultílogos. Además, expulsaron de la literatura dramática algunos de los rasgos más afines al ingenio del loco y el chocarrero, a la risa del disparate y a la tradición de la farsa. Fruto de esta querida y también impuesta racionalización moral, algunos de los defectos del marido del entremés - cornudo, manso y consentidor- pasaron a un renovado tipo de pretendiente, el cortejo. No fue ajena a este trasvase irrisorio y descalificador, una razón extraliteraria de gran peso: la preocupación por el matrimonio de la Ilustración coetánea, obsesionada por conseguir la armonía conyugal, paternofilial, doméstica y social y, por tanto, contraria a las bodas desiguales concertadas para obtener un título nobiliario o entre hombres muy maduros con muchachas ${ }^{22}$. Hay otras concausas de alcance político más general: el rechazo de la inutilidad social que desemboca en la frivolidad ociosa y pecaminosa (como los moralistas cristianos habían afirmado siempre) y en el lujo y el consumo de productos extranjeros: El señorito mimado y La señorita malcriada, de Tomás de Iriarte, teatralizan y condenan algunos de los defectos que dan pie a la burla y la sátira de los sainetes de Ramón de la Cruz. Asimismo, existe una preocupación también moral y económica por la escasez de bodas, incluso por lo onerosas que podían resultar: tras casar al primogénito, el padre inclina «al estado eclesiástico,

${ }^{21}$ El Pensador. Madrid: Impr. de Joachin Ibarra, 1763, I, pensamiento vii, pp. 9 y 10 respectivamente; ed. facsímil: Madrid: Universidad de Las Palmas de Gran Canaria - Cabildo de Lanzarote - Biblioteca Nacional de Madrid, 1999.

${ }^{22}$ Valga como ejemplo mi artículo «Los afectos sociales y domésticos en el teatro de Leandro Fernández de Moratín: el beso de doña Francisca y Rita». En: FERNÁNDEZ, R. y SOUBEYROUX, J. (eds). Historia social y literatura. I. Familia y clases populares en España (siglos XVIII y XIX), Lérida - Saint-Étienne: Milenio / Université Jean Monnet, 2001, pp. 113-129; consultable en cervantesvirtual.com. 
secular o regular, particularmente a los tímidos y a las pobre hijas ${ }^{23}$, lo cual ayuda a explicar la escasa religiosidad de los abates según los sainetes que los ponen en solfa. Por todo ello, y por la propia evolución de un género que no rehúye la caricatura de las "anormalidades" coetáneas, el blanco de las flechas se desplazó un tanto hacia el cortejo, aunque ni los ilustrados más modernos ni los tradicionalistas más antiguos dejaron del todo de apuntar con su arco certero al marido.

\section{El Entremés de los Gurruminos, de Antonio de Zamora}

De acuerdo con los apartados anteriores, la permeabilidad del teatro breve asegura la larga continuidad de muchos de sus elementos, a la vez que favorece su renovación, atentos sus autores a cualquier estímulo procedente de la realidad o de otros códigos parodiables. Por tanto, además de remitir al contexto histórico, el cortejo no es sino un jalón más en el camino de un tipo, figura o figurón que en el teatro barroco se encarna de diversas maneras: el viejo tutor que desea casarse con la ingenua que tan celosamente guarda; el hidalgo de lugar con su indumentaria ridícula y su presunción; o la muy variada gama en posibilidades económicas y edad de los pretendientes, desde el doctor y el boticario al barbero y el estudiante. También el sacristán mujeriego que habla un latín macarrónico e imposible precede en una misma trayectoria funcional al abate.

Una misma risa une el lindo al gurrumino y éste a los usías que aceptan las nuevas formas del galanteo a mujeres casadas. «El personaje del entremés es ante todo apariencia corporal, vestido y porte» ${ }^{24}$, y todos los pisaverdes dieciochescos salen al teatro con una apariencia, indumentaria y apostura similares, con una obsesión por la ropa muy parecida. La falta de virilidad de un lindo don Diego, que «tan ajustado se viste / que al andar sale de quicio» ${ }^{25}$ y la falta de autoridad del marido condescendiente (llegue o no al clásico cabrón dorado) se reencarnan en el gurrumino, en el cortejo y en el currutaco; a veces, también en el abate y el oficial militar que aspiran a cumplir los caprichos de una dama sin reales posibilidades económicas.

${ }^{23}$ ROMERO DEL ÁLAMO, Manuel. «Carta a los señores editores del Memorial literario sobre las causas de la despoblación de España». Memorial Literario. abril 1789 (parte II), pp. 623-638; la cita en p. 638. Apud Larriba, Elisabel y Dufour, Gérard (eds.). «Clero y opinión pública ante el celibato. De la Ilustración al Liberalismo». En: FERNÁNDEZ, R. y SOUBEYROUX, Gérard (eds.). Historia social y literatura. III. Familia y clero en España (siglos XVIII y XIX), Lérida - Saint-Étienne: Milenio / Université Jean Monnet / Universitat de Lleida, 2004, pp. 145-161; la cita en p. 153.

${ }^{24}$ MARTÍNEZ LÓPEZ, M. J., op. cit., p. 151.

${ }^{25}$ MORETO, Agustín de. El lindo don Diego. Casa, F. y. Primorac, B. (eds.). Madrid: Cátedra, 1977, versos 325-326. 
Relacionados con el lindo, los gurruminos, que dan título a uno de los mejores entremeses de Antonio de Zamora, son maridos que parecen petimetres $^{26} ; \mathrm{y}$, de ser cierto lo afirmado por María Luisa Mayayo Vicente, su origen sería mucho más el fruto de una tentativa de renovación de la tipología teatral que la consecuencia de una aproximación al contexto social:

Acerca del personaje del/la gurrumino/a, hay que decir que son una clara manifestación del gusto barroco por las inversiones (los gurruminos son hombres y mujeres casados que adoptan en su matrimonio el papel teóricamente propio del sexo contrario $)^{27}$.

El propio Entremés de los gurruminos aclara qué se entiende por el término cuando el alcalde Gil Pollina proporciona su motivo inicial: va a dictar un bando prohibiendo a los gurruminos, que consienten «en todas las ocasiones / que su mujer se ponga los calzones» (versos 9-10). El castigo aúna la ridiculización de la indumentaria y las "evidencias" de su falta de virilidad:

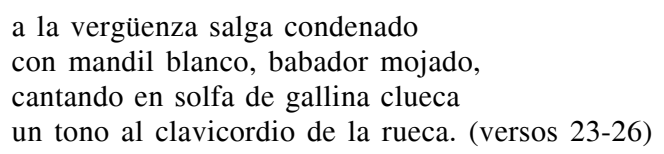

En el teatro, la rueca es a menudo metonimia icónica y verbal que simboliza a la mujer. Por su parte, las gallinas cluecas pueden servir en el habla masculina de los intermedios como símil animalizador y, por tanto, degradante de las mujeres parideras.

La tradición entremesil del Entremés de los gurruminos se hace presente en la retahíla de insultos con que su mujer, la alcaldesa, atemoriza a Gil. La sucesiva aparición de gurruminos ilustra el rechazo de los nuevos calzonazos, que se distinguen de la tradición del esposo de genio blando por su servilismo nuevo y "dieciochesco". He aquí la conclusión, compartida sin duda por las risas del público y provocada por un diálogo de los primeros gurruminos:

$\begin{array}{ll}\text { DOÑA ALDA. } & \begin{array}{l}\text { Sí, pero al cuerpo no es el aire sano, } \\ \text { como vengo vestida de verano. }\end{array} \\ \text { DON CRISPÍN. } & \text { Ponte mi capa, daca tu mantilla. }\end{array}$

${ }^{26}$ Entremés de los gurrumino. En Comedias nuevas, con los mismos saynetes con que se executaron... Madrid: Diego Martínez Abad, 1722; para las citas, empleo la ed. de DOMÉNECH RICO, F. Antología del teatro breve español del siglo XVIII. Madrid: Biblioteca Nueva, 1997, pp. 159-181.

${ }^{27}$ «Sobre los entremeses de Antonio de Zamora». En: HUERTA CALVO, J; BOER, H. DE.y SIERRA MARTÍNEZ, F. (eds.). El teatro español a fines del siglo XVII. Historia, cultura y teatro en la España de Carlos II. Volumen II. Dramaturgos y géneros de las postrimerías. Amsterdam: Rodopi, 1989, pp. 543-552; la cita en p. 545. 


$\begin{array}{ll}\text { DOA ALDA. } & \text { ¿Y qué dirá la gente de la villa? } \\ \text { DON CRISPÍN. } & \begin{array}{l}\text { Que quiero a mi mujer; y que la halague } \\ \text { nadie me ha de culpar. } \\ \text { (Truecan.) }\end{array} \\ \begin{array}{ll}\text { DOÑA ALDA. } & \text { Dios te lo pague. } \\ \text { ALGUACIL. } & \text { Bueno va el maricón. (versos 77-83) }\end{array}\end{array}$

El cambio de prendas de vestir visualiza y teatraliza la inversión, con un alcance que, sin excluir lo grotesco característico de la cultura carnavalesca (el obispillo, la mujeres mandando por santa Águeda, incluso la vieja preñada...), cumple ya una cierta función satírica. Obviamente, la nueva condición gurrumina no excluye la vieja codicia de la mujer, interesada por el dinero y no por el amor: «pensaba el niño / que lo que es conveniencia era cariño» (versos 93-94), ya que se trata de una degradación de la persona que cruza todo el teatro burlesco: tampoco las madamas querrán a sus cortejos petimetres, de los que se valen para no aparecer solas o con sus maridos en público y para satisfacer sus caprichos. Únicamente en la mirada y el contoneo de las majas, incluso en algunas de sus réplicas dictadas por la agudeza verbal y la sinceridad podrá percibirse el deseo sexual, lo que resulta imposible en las normas hipócritas que fundamentan el trato petimetril ${ }^{28}$

Una vez se llevan del tablado al gurrumino Crispín «a empellones, / ya que no hay de qué asir en los calzones» (versos 101-102), otra pareja sale a escena. Tras el desarrollo lingüístico, una didascalia describe la inversión, en este caso de las tareas domésticas: doña Simona toca la guitarra mientras don Efis canta y friega con un barreño y un estropajo grande. El antifraseo entre lo que se dice y lo que se hace mueve a risa en el caso del tercer gurrumino, don Plácido, que aparece furioso blandiendo una espada y termina llorando al lado de su mujer, doña Estufa, al fingir ella un desmayo «haciendo visajes», uno de los recursos irrisorios habituales también en los sainetes de la segunda mitad del siglo XVIII. La sintaxis dramáticonarrativa del Entremés de los gorriones repite una vez más el desfile de casos ridículos (aquí desarrollados verbal y extraverbalmente) ante un "juez", degradado en alcalde pollino. La estructura de la obra muestra la habilidad del autor con una posterior intensificación de la acción gracias a la salida al escenario de los tres gurruminos «con delantales blancos

${ }^{28}$ No puedo extenderme, pero las tonadillas y su representación así lo certifican. Respecto a los sainetes, valga como botón de muestra esta declaración de la maja Inés, en la que se queja de la imposibilidad de mantener verdaderas relaciones (y no la mera aceptación de regalos a cambio de favores) con un hombre de estamento social superior: «Mi pecado, lo confieso, / es el querer a un ingrato. / Pero solamente siento / que la más encopetada / no está libre de este yerro; / y lo que en mí es un delito, / es en otra pasatiempo» (GONZÁLEZ DEL CASTILLO, J. I. La maja resuelta, Obras completas, Madrid: Libr. de los Suc. de Hernando - Real Academia Española, 1914, II, p. 124). 
y ruecas» (acotación $200+$ ), para cantar e hilar y obligar al alcalde a vestirse como ellos y a hacer lo mismo. Concatenada con el inicio, pues el alcalde también carecía de autoridad ante su esposa, esta nueva inversión supone el desenlace, con un movimiento en procesión de mujeres y de hombres hasta desaparecer de escena, a lo que sigue una breve conclusión cantada. La solución es muy teatral y eficaz: cantan

$$
\begin{array}{ll}
\text { ÉL y TODOS. } & \begin{array}{l}
\text { Lilao, lilao, } \\
\text { que soy clueca y parezco gallo. }
\end{array} \\
\text { MuJERES. } & \text { Anden los maricones, bachilleres. } \\
\text { HOMBRES. } & \text { Aunque nos casquen, vivan las mujeres. } \\
& \quad \text { (versos 227-230) }
\end{array}
$$

El ultílogo remata:

$$
\begin{array}{ll}
\text { ALCALDESA. } & \text { (Canta.) Di cuántos gurruminos } \\
\text { hay en la Corte. } \\
\text { ALCALDE. } & \begin{array}{l}
\text { (Canta.) Si son hombres, hay, niña, } \\
\text { tantos como hombres. (versos 235-238) }
\end{array}
\end{array}
$$

La pervivencia de su actualidad, al menos teatral, del gurrumino queda ratificada porque los manuscritos y ediciones sueltas «muestran que era una obra típica de repertorio» ${ }^{29}$ y se programa una y otra vez, por ejemplo entre 1763 y 1779, en los teatros del Príncipe y de la Cruz de Madrid $^{30}$. Convive, por tanto, en la cartelera con sainetes nuevos de Juan de Agramont y Toledo, varias piezas sobre la petimetría de Ramón de la Cruz o Los payos de Trillo (1781), de Sebastián Vázquez.

El Entremés de las gurruminas ${ }^{31}$, del propio Zamora, no tiene tanto interés y, sin duda, tuvo menos suerte: únicamente subió a los escenarios en $1721^{32}$. La pieza invierte las funciones de los personajes del Entremés de los gurruminos; en este caso, es una mujer la que dicta el bando con el objeto de oponerse a que otras hagan las veces de los maridos por un exceso de amor. Los gags o efectos burlescos reiteran, pues, la comicidad del Entremés de los gurruminos; por ejemplo, si en éste doña Simona toca la

${ }^{29}$ DOMÉNECH, Fernando. «Introducción». Antología..., op. cit., p. 57.

${ }^{30}$ ANDIOC, René y COULON, Mireille. Cartelera teatral madrileña del siglo XVIII (1708-1808). Madrid: Fundación Universitaria Española, 2008, II p. 741.

${ }^{31}$ Comedias nuevas, con los mismos saynetes con que executaron... Madrid: Diego Martínez Abad, 1722, tomo I. (He utilizado una copia que se guarda en el Institut del Teatre de Barcelona, 46901.)

${ }^{32}$ Ibid. Juan F. Fernández Gómez apunta «Existió otro E[entremés] con este título de Alonso Sánchez Tórtoles (de 1671), pero con cens[ura] de 1729, así como un baile entremesado, anónimo, del siglo XVIII». (Catálogo de entremeses y sainetes del siglo XVIII. Oviedo: Universidad de Oviedo - IFESXVIII, 1993, p. 337, entrada 991). Ignoro si el texto de Sánchez Tórtoles es tan antiguo y si su título inicial fue ya Entremés de las gurruminas. 
guitarra mientras su esposo friega y lava los platos, en aquél la mujer del barbero lo sustituye en su oficio para que él pueda dedicarse a tañerla. Resulta evidente que la tradición misógina y la herencia del marido calzonazos poseían mucha más eficacia cómica que la insólita pasión de las mujeres por sus cónyuges.

\section{LOS GUSTOS DE LAS MUJERES Y LO QUE PASAN LOS MARIDOS, DE JUAN DE AGRAMONT Y TOLEDO}

La obra de Agramont es inmediatamente anterior y también coetánea a la de Ramón de la Cruz y, a pesar de que siga en buena medida los códigos entremesiles, atestigua ya el mencionado acercamiento dramático a las nuevas formas de relación social:

Con todo, se percibe en los tipos femeninos y en la milenaria burla misógina una relativa aproximación a los nuevos usos y costumbres de las mujeres, criticados, evidentemente, desde la defensa de valores tradicionalistas: la sobriedad, la discreción, el recato, la obediencia. Todavía no es así en doña Laureana y doña Nufla de El desafío sin armas (1761) — por contraste con El hospital de la moda, también de 1761, de Ramón de la Cruz-, pero en Los gustos de las mujeres o en Lo que pasan los maridos, la aplaudidísima burla de la capacidad despilfarradora de las mujeres se reviste de alusiones al nuevo consumo y se une, a la vieja crítica de las mujeres ventaneras, la condena de su incipiente independencia ${ }^{33}$.

Los gustos de las mujeres ${ }^{34}$ es un «entremés nuevo» de mediados del siglo XVIII, aunque se suma a tantos otros dedicados a satirizar a las mujeres de centurias anteriores. Con el gracioso Ayala como juez, una buena parte de la comicidad de la pieza radica en que siete actrices aparecen vestidas de hombres y, algo después, los actores de mujeres. Algunos de los defectos que desfilan en la revista de personajes son muy habituales en el teatro breve y la literatura de cordel, pero otros remiten en cierto grado a las demasías femeninas en materia de independencia, consumo, etc. Una ridiculización que va a tener cierta fortuna en sainetes posteriores se basa en el amor desmedido de las madamas por sus perros, lo que Agramont lleva al absurdo con el vejete disfrazado de «mujer ridícula», como otros miembros de la compañía pero, en su caso, mostrando su amor maternal por los tres o cuatro gozques que lleva en una cesta.

El juez dicta sentencia ante este mundo al revés, en que las esposas imponen sus caprichos a los maridos, y obliga a cambiarse de ropa; así, la inversión inicial da paso a un regreso a la normalidad. El recurso es muy

${ }^{33}$ SALA VALLDAURA, Josep Maria. «Juan de Agramont y Toledo en el teatro breve del siglo XVIII». (spring 2004), Dieciocho 27,1, pp. 75-87; la cita en p. 80.

${ }^{34}$ Biblioteca Nacional de Madrid, mss. 16266 (2). (En las citas, modernizo su grafía y puntuación) 
teatral y posee bastante relieve satírico, que el parlamento de Ayala refrenda: Una mujer es borracha

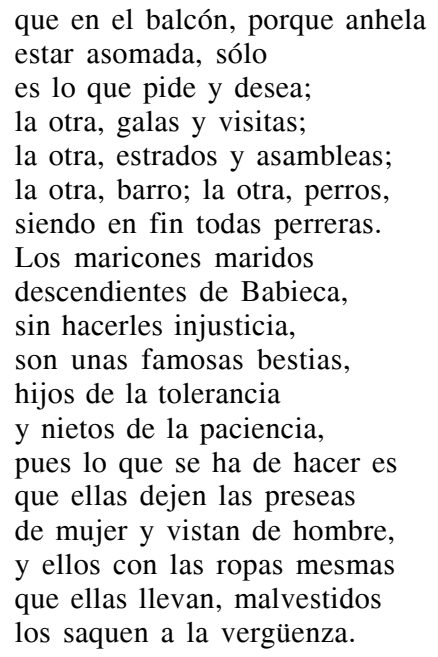

Poco antes de que todos salgan de escena y empiece el canto, Paca remacha con una moraleja que no remite a los ultílogos característicos del neoclasicismo horaciano, sino que muestra la pervivencia de unos valores que situaban la excelencia moral femenina en el ámbito de la obediencia:

$$
\begin{aligned}
& \text { PACA. Y dando a la Corte vuelta, } \\
& \text { sepa Ayala y sepa el mundo } \\
& \text { que las mujeres más tercas, } \\
& \text { llevadas por mal, son malas, } \\
& \text { llevadas por bien, son buenas. }
\end{aligned}
$$

El deseo de mudar las costumbres de Madrid, según el encabezamiento de esta réplica, puede ser vinculado a mucha literatura satírica coetánea. Sin embargo, hay que subrayar (y no soslayar) que evidencia el secular tópico del menosprecio moral de la corte, plenamente vigente incluso cuando la ingenuidad de los payos y, sobre todo, de las payas, es contrapuesta a la perversidad de las clases adineradas urbanas, especialmente, de los petimetres. Por otro lado, resulta fácil encontrar muchas afinidades entre esta pieza y el Entremés de los gurruminos, de Zamora: la función axial del juez o el alcalde, la debilidad de los hombres, los excesos de las mujeres, el desarrollo argumental con la ayuda del travestismo, la conclusión con que se cierra el desfile, la propia sintaxis dramáticonarrativa, etc.

Lo que pasan los maridos ${ }^{35}$ ejemplifica, al igual que Los gustos de las mujeres, los entremeses

${ }^{35}$ Biblioteca Nacional de Madrid, mss. 16266 (10). 
de revista de personajes o desfile de figuras, cuya estructura se fundamenta precisamente en el desfile sistemático de personajes estereotipados, o sea figuras, ante un juez, árbitro o examinador que los califica en sus defectos o manías, poniendo de manifiesto su lado ridículo ${ }^{36}$.

Ambas piezas de Juan de Agramont y Toledo también guardan muchos puntos en común, ya que explotan la misma veta cómica de Ayala, la indiferenciación de los personajes respecto a los actores y una parecida crítica al talante de las mujeres, si bien el motivo inicial de Lo que pasan los maridos es el de buscar esposa. La sucesión de los consejos que diversos esposos le dan yuxtapone y aporta razones contra el casarse. Agramont ya traza verbalmente los rasgos de las madamas que arruinan la economía familiar exigiendo ropa, peluquero, coche... Las réplicas de las féminas lo van corroborando, hasta que sale a escena Mariana como representante del gracejo popular; Ayala se decanta entonces por ella:

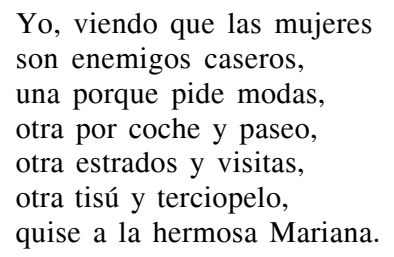

Es la victoria de la naturalidad de gestos y palabras frente al artificio de quienes, como las petimetras, optan por un erotismo recubridor del cuerpo. De este modo, Lo que pasan los maridos de Agramont es una muestra muy temprana de la bipolarización teatral entre la petimetría y el majismo, resuelta a favor de éste por la obvia complicidad con gran parte del público, y no sólo el popular. El desenlace se beneficia de algún juego lingüístico; verbigracia, el equívoco homofónico y la silepsis: Paca pide «[...] que mi esposo me compre / los nuevos usos» y Ayala replica:

Muy bueno.

Pues toma, para que hiles,

la rueca y dos husos nuevos.

Y, por fin, el entremés recuerda su herencia farsesca y apela a la acción con garrotazos y embestidas, mientras los hombres se arrodillan o lloran, incapaces de negar los caprichos de sus esposas.

\section{LOS PETIMETRES Y LOS ABATES}

En el personaje del "cortejo" se incardina una cierta exageración teatralizadora, que busca también subrayar diferencias entre el petimetre y el

${ }^{36}$ HUERTA CALVO, J., op. cit., p. 61. 
majo, que los caricaturiza incluso, con el fin de oponer, más allá de la realidad coetánea, lo extranjero y afeminado de uno a lo castizo y viril del otro. Alberto González Troyano llega a hablar de analogías entre «el petimetre, deseoso de asumir todas las modas por el solo hecho de ser nuevas, y la predisposición modernizadora de muchos burgueses ilustrados» ${ }^{37}$, y Joaquín Álvarez Barrientos recurre a la indumentaria y a las aficiones de Jovellanos y otros intelectuales de la época para afirmar hasta qué punto la ridiculización de las nuevas modas y de las nuevas formas de comunicación puede ocultar una nueva manera de entender y practicar la cultura $^{38}$. En cualquier caso, el petimetre como caricatura de la realidad, como figurón del teatro breve, se aprovecha de «los hábitos cosmopolitas y foráneos» de un mundo esnob «colindante con la petimetría» ${ }^{39}$, pero ello no niega la existencia de una base real, que detectan, entre otros, el buen sainetero Ramón de la Cruz y Nicolás Fernández de Moratín, con la comedia La Petimetra (1762). Baste con el testimonio de J. François Bourgoing: en España, a los cortejos «se les exige una entrega total. Tienen que estar dando pruebas de ella a todas horas con su compañía al paseo, a los espectáculos y hasta al confesionario» ${ }^{40}$.

En una metáfora encadenada que aún recuerda la visión carnavalesca o la oposición entre el ser y el aparecer barroco, el mundo ha enfermado: Ramón de la Cruz crea sobre el tablado y bajo la mofa de la risa un hospital de la moda ${ }^{41}$. Entre sus pacientes, el petimetre cortejo que, siguiendo con el parecer de El Pensador,

\begin{abstract}
es un Duende aéreo, que va y viene, corre, bulle, salta, brinca y se zarandea en los cerebros de gentes ociosas, sin hacer bien ni daño, sin ser malo ni bueno, sin saberse si es carne o pescado. Pero no es éste el cortejo de que tratamos. El que está en uso podría definirse así: Es un pretexto, a cuya sombra se pasean muchos escándalos, disfrazados bajo los especiosos títulos de obsequio, reconocimiento y amistad; o de este modo: Es un enemigo de las buenas costumbres, a quien dan acogida ciertas gentes de humor extravagante y caprichoso, por no decir depravado $^{42}$.
\end{abstract}

37 «El petimetre: una singularidad literaria dieciochesca». Monográfico sobre Ramón de la Cruz: Insula, 574 (octubre 1994), pp. 20-21; la cita en p. 21 b.

${ }^{38}$ Remito a Los hombres de letras en la España del siglo XVIII. Apóstoles y arribistas. Madrid: Castalia, 2006.

${ }^{39}$ GONZÁLEZ TROYANO, A. «Signos de modernidad gaditana: la moda y la coquetería». En ROMERO FERRER, A. (ed.). Juan Ignacio González del Castillo (1763-1800). Estudios sobre su obra. Cádiz: Fundación Municipal de Cultura del Ayuntamiento de Cádiz / Universidad de Cádiz, 2005, pp. 143-152; la cita, en p. 144.

${ }^{40}$ Nouveau voyage en Espagne ou tableau de l'état actuel de cette monarchie. París: 1788, 3 vols., II p. 296; apud MARTÍN GAITE, C., op. cit., p. 165.

${ }^{41}$ El hospital es un espacio escenográfico simbólico, bastante usado por los intermedios; véase ASENSIO, Eugenio. Itinerario del entremés desde Lope de Rueda a Quiñones de Benavente. Madrid:Gredos, 1965, pp. 86-88.

${ }^{42}$ El Pensador, op. cit., I, iv, pp. 17-18; la cita que sigue, en pp. 21-22. 
Por esta sinrazón, «un hombre iniciado de loco, con sus ciertos ribetes de calavera, ignorante y presumido es el más propio y solicitado para cortejo». Los sainetes de Ramón de la Cruz le niegan la posibilidad de expresar verdaderos sentimientos; la tradición entremesil arrinconaba el amor y, por otra parte, jamás un teatro comercial del siglo XVIII hubiera podido estrenar un sainete en el que un hombre y una mujer se quisieran de veras fuera del matrimonio.

En tal imposibilidad de sinceridad afectiva, la degradación caricaturesca llega hasta la falta de virilidad, en el punto opuesto a «la apariencia de una falsa virilidad, característica de los baladrones» ${ }^{43}$. Desde Ramón de la Cruz y a lo largo de toda la centuria, el petimetre y, con él, el abate lo ponen de relieve en el escenario del teatro breve saliendo vestidos ridículamente y de manera muy ceñida, sin "sobriedad" masculina, a veces anunciándose por el ruido que el entrechocar de sus joyas y relojes provoca. Con verlos, el público puede menospreciarlos también por su peinado, su maquillaje, su barba rasurada, su corto espadín, su forma de andar o brincar, pues a menudo dan grotescos saltitos pese a su edad provecta. Hacen cortesías a la francesa y monerías y, en su excesiva "finura", melindrean y hasta algunos afectan damerías y dengues. Cuchichean y murmuran mujerilmente, hablan de manera pedante y artificiosa de temas tan femeninos como la moda, carecen de entendimiento y esfuerzo intelectual. Ignoran la autoridad propia de los hombres, son cobardes y maledicientes, y de ahí que se comporten como mujeres en las visitas, que cosan o que cojan en brazos a un perro faldero.

En cuanto a los abates,

resultan ser ridículos, poseedores de una cierta cultura, pero fatuos, y pseudoeruditos en realidad, que se dedican a escribir obras supuestamente magnas. Son presumidos, lindos y afeminados, iracundos y lascivos a veces, amantes del buen comer hasta llegar al exceso, hipócritas y faltos de caridad, egoístas e interesados $^{44}$.

La caricatura que de ellos hace Diego de Torres Villarroel esboza ya algunas de sus costumbres, su afición por las casas ajenas y su desinterés por el estudio y la meditación:

son presbíteros miqueletes, dragones de la clerecía, que tanto hacen a pie como a caballo. Son los ganchosos y los escarramanes del estado eclesiástico, sacerdotes un cuarto de hora y salvajes todo el año. Éstos tienen más visitas que los doctores, viven de día y noche en los estrados; son dueñas sin toca ni monjiles, Colo-

${ }^{43}$ SALA VALLDAURA, J. M. El sainete en la segunda mitad del siglo XVIII. La mueca de Talía. Lérida: Universitat de Lleida, 1994, p. 107.

${ }^{44}$ CAÑAS MURILLO, J. «Hacia una poética del sainete: de Ramón de la Cruz a Juan Ignacio González del Castillo». En: SALA VALLDAURA, J. M. (ed.). Teatro español del siglo XVIII. Lérida: Universitat de Lleida, 1996, I, pp. 209-241; la cita en p. 220. 
nes de los refrescos y las tarariras. Tres géneros de gente visten este traje: los párrocos monteses, los segundos y terceros de los mayorazgos y los tunantes perpetuos $^{45}$.

Torres Villarroel y, después, los saineteros olvidan al menos un cuarto género de abates, presente en la sociedad intelectual del siglo XVIII: los hombres de letras que cambiaron los circuitos de transmisión del saber y acercaron oralmente y por escrito sus conocimientos y creaciones a un público más amplio. En los intermedios, sin embargo, los abates sirven únicamente de correveidiles, de cortejos sin arte ni parte, de maestros ignorantes de música o gramática o de administradores sin oficio y con beneficio $^{46}$. Y rivalizan con ventaja como chismosos; por esto, en La elección de cortejo (1767) se aguarda al "avechucho" (es decir, abate) don Mauricio, «que no hay uno / que sepa los embelecos / de Madrid como él los $s^{2} e^{47} »$, y que informará de este anuncio u oferta de "empleo":

$$
\begin{aligned}
& \text { «El tabernero } \\
& \text { junto a la botica en la } \\
& \text { calle de los Pasatiempos } \\
& \text { dará razón de una dama } \\
& \text { que necesita un cortejo } \\
& \text { joven y rico, que sepa } \\
& \text { adular, rizar el pelo } \\
& \text { y mondar melocotones». }
\end{aligned}
$$

Como puede observarse, en cuanto a los petimetres, se dedican a satisfacer los caprichos más estúpidos de las madamas, soportan sus quejas más peregrinas, fingen pasiones y elogios, valen como bastoneros de bailes franceses... Unos y otros, petimetres y abates, pueden reponer los simulados desmayos con succino.

\section{RAMÓN DE LA CRUZ}

El abate renueva a la vez que prosigue el tipo del sacristán ${ }^{48}$, y el petimetre prolonga, según vimos, al lindo y al gurrumino. A comienzos

${ }^{45}$ «Los abates». En: SEBOLD, R.P. (ed.).. Visiones y visitas de Torres con don Francisco de Quevedo por la corte. Madrid: Espasa Calpe, 1966, p. 206.

${ }^{46}$ Sobre esto último, vale la pena leer Despedido quien despide (1774), de Pablo Esteve; comento las particularidades de su protagonista, el abate don Cleofás, en «Pablo Esteve, sainetero». En Álvarez Barrientos, J. y Lolo, B. (eds.). Teatro y Música en España: los géneros breves en la segunda mitad del siglo XVIII. Madrid: Universidad Autónoma de Madrid / CSIC, 2008, pp. 325-350, esp. pp. 331-336.

${ }^{47}$ Sainetes, ed. cit. Cotarelo y Mori, I, p. 356 b; la cita que sigue, en p. 357 a.

${ }^{48}$ Véanse mis trabajos «El papel del abate en Ramón de la Cruz». En:. SALA VALLDAURA, J. M. (ed.). Teatro..., op. cit., II, pp. 707-734 y «Tradición teatral y realidad 
de la década de los sesenta, Ramón de la Cruz fija ya en buena medida la burla y hasta la "sátira social" de la petimetría en el teatro breve de la segunda mitad del siglo XVIII: El hospital de la moda, La petimetra en el tocador (1762) y El petimetre $(1764)^{49}$. Poco después, en 1767, el propio autor madrileño ironiza sobre el tema:

\begin{tabular}{ll} 
EUSEBIO. & \multicolumn{1}{c}{$\begin{array}{c}\text { Porque sé de cierto } \\
\text { que van a dar un sainete } \\
\text { criticando a los cortejos, } \\
\text { y estamos ya corrompidos } \\
\text { de tan común argumento. [...] }\end{array}$} \\
& Como es ésa una materia \\
tan amena y donde hay nuevos \\
casos cada día, es preciso \\
que se repita el objeto
\end{tabular}

En El petimetre, don Soplado da a conocer su banalidad y su exclusiva preocupación por el acicalamiento en una primera escena con el peluquero; llegarán luego don Mónico, el sensato don Modesto y el abate don Zoilo, que irán conformando los rasgos jocosos de los enfermos del mal de moda, opuestos a la normalidad moral tradicional tildada por el abate de «gentiles extravagancias» ${ }^{51}$. La ironía con que hay que interpretar el comentario de Zoilo sitúa al espectador como juez por poderse considerar como moralmente superior. En cambio, no hay ironía en este comentario sobre el uso del jabón: «DON MODESTO. No es en los hombres / mucho primor manos blandas», porque se opone la rusticidad al afeminamiento de un exceso en el aseo y el cuidado personal. Así razona el protagonista:

DON SOPLADO.

$$
\begin{aligned}
& \text { no puede haber mayor tacha } \\
& \text { en un hombre de honor, ni } \\
& \text { puede hacer mayor infamia, } \\
& \text { que profanar un estrado } \\
& \text { con las medias arrugadas. }
\end{aligned}
$$

A lo largo de toda su obra teatral, Cruz subirá a escena a estos personajes en un alto número de piezas. Ya sean ancianos como los dos de $E l$ viejo a la moda (1772), ya jóvenes acanallados como don Felipe, protagonista de El hijito de vecino (1774), provocan la risa de un público que se

social: del sacristán al abate en el teatro breve del siglo XVIII». En: FERNÁNDEZ; R. y SOUBEYROUX, J. (eds.). Historia social y literatura. III. Familia y clero..., op. cit., pp. 39-57.

${ }^{49}$ Remito a M. Coulon, op. cit., esp. cap. VII, pp. 419-476.

${ }^{50}$ La elección de cortejo, Sainetes, ed. cit. de E. Cotarelo y Mori, I p. 356 b.

${ }^{51}$ Doce sainetes. GATTI, J. F. (ed.). Barcelona: Labor, 1972, p. 68, verso 230; las citas que siguen, ibid., versos 237-238 y 249-254. 
siente superior ante un antihéroe incapaz de despertar simpatía o piedad. Pertenecen a un grupo social probablemente más alto que el de muchos espectadores o, al menos, así lo fingen, porque algunos no son más que «usías de medio pelo». Son de una inutilidad clara en amor, dinero, religión y trabajo y carecen de las cualidades propias del hombre de bien o del hombre, tout court. La coartada jocosa que abre el paréntesis de la risa es múltiple: se fundamenta en la condenable pobreza intelectual y en la frivolidad moral de ciertos sectores de clase media y alta urbana, en las nocivas consecuencias económicas de la inutilidad de unos y el capricho de otras. Es cierto que, cercano el final del siglo, el Diccionario de Terreros recogerá un cambio en la percepción del petimetre (o "petrimetre", como se lee en él): «se toma también en castellano por el que anda limpio, compuesto y bien vestido, etc., sin declinar en nimiedad ${ }^{52}$, pero la codificación teatral proseguirá su camino hasta nutrir el costumbrismo literario y gráfico de principios del siglo XIX y alimentarse de él.

En La oposición a cortejo (1773) se lee una de las réplicas que mejor sintetiza los defectos que se critica en la figura del petimetre, que en las obras de Cruz no parece tener otra tarea que la de cortejar una o varias madamas:

$$
\begin{aligned}
& \text { Yo por vos he tolerado } \\
& \text { que me desuelle el barbero } \\
& \text { todos los días; por vos } \\
& \text { he desmentido mi sexo, } \\
& \text { ya al tocador, porque fuera } \\
& \text { mi peinado el más perfecto, } \\
& \text { ya bordando en cañamazo } \\
& \text { a vuestro lado, o ya haciendo } \\
& \text { bufandas; por vos con todos } \\
& \text { mis parientes indispuesto } \\
& \text { vivo; por vos renuncié } \\
& \text { los más brillantes ascensos, } \\
& \text { que fuera de aquí me daba } \\
& \text { la carrera que profeso; } \\
& \text { por vos jamás voy a misa, } \\
& \text { sino el día de precepto; } \\
& \text { por vos soy un animal, } \\
& \text { pues ni me aplico ni leo, } \\
& \text { y sólo sé hablar de modas } \\
& \text { o murmurar, que son, cierto, } \\
& \text { en un hombre conocido } \\
& \text { muy apreciables talentos }
\end{aligned}
$$

52 TERREROS y PANDO, E. Diccionario castellano con las voces de ciencias y artes... Madrid: Viuda de Ibarra, 1786-1793, 4 vols.

${ }^{53}$ Sainetes. Sala Valldaura, J. M. (ed.); Bittoun-Debruyne, N. (col.). Barcelona: Crítica, 1996, pp. 233-234, versos 55-76. 
Por tanto, los perjuicios que ocasiona la petimetría son de índole personal, familiar, profesional, cultural, religiosa y social. En el terreno sexual, el cuidado masculino por la apariencia — siempre excesivo, según los octosílabos de los sainetes- resulta contraproducente: los verderones no atraen, en algunas ocasiones porque, en su retrato grotesco, se suma a otras "ridiculeces" la de ser ancianos desdentados y repugnantes.

La rapidez de la caracterización que exige el teatro breve contribuye a dar importancia temática a la indumentaria, pero también la música adquiere un gran papel en la conformación dual de muchos sainetes, al contraponer los bailes españoles, desde las seguidillas hasta el fandango y el olé andaluz, al minuet y la contradanza de origen francés. El vestuario (junto con peinado, gestos, etc.) y la música gozan de una gran eficacia expresiva, que sirve para enfrentar dos maneras de vivir, a favor siempre de la que se considera más alegre y más española. Ese nacionalismo cultural se manifiesta con rotunda claridad en los sainetes con caballeros plebeyistas que abominan de lo nuevo y extranjero. El transclasamiento de estos señores es tratado con cierta simpatía por Ramón de la Cruz, pues, al fin y al cabo, corroboran la prevalencia de lo nacional y fortalecen las raíces patrióticas.

En El deseo de seguidillas (1769), la afición de don Pedro por la gente y las diversiones del pueblo llano se evidencia al salir al tablado «de capa y peluquín y chupa, a lo majo usía ${ }^{54}$. Frente a los petimetres asexuados, afeminados o incapaces de amar, que tildan el gusto de don Pedro de "perverso", "vil" y "chabacano", el joven plebeyista muestra su virilidad, así como el entusiasmo y el deseo erótico de quien tiene alegría de vivir:

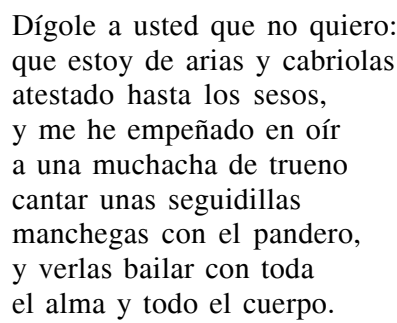

\section{JuAn Ignacio GonZÁlez del CASTILlo y los CURRUTACos}

La redundancia en la codificación de petimetres y abates permite la fácil comprensión de los espectadores y su economía intelectual, ambas favorecedoras de la risa franca. Juan Ignacio González del Castillo (1763-1800) continúa en varias obras la mofa de unos personajes que, sin tanta exage-

${ }^{54}$ Ibid., p. 114; las citas que siguen, pp. 117, versos 46-47 y 54-62 respectivamente. 
ración, también debían pasearse por una ciudad tan cosmopolita como Cádiz. Entre estos sainetes «satíricos de costumbres» - y, más particularmente, «de ambientes urbanos» y «de las clases altas»- ${ }^{55}$, El cortejo sustituto destaca porque la labor del protagonista, don Pedro, permite compendiar en un volumen los defectos de las madamas. Entre sus tareas de cortejante, las consabidas:

\author{
Con unas sólo me obligo \\ a llevarlas al teatro, \\ al paseo, a la visita; \\ y con otras me contrato \\ para el tocador, la mesa, \\ la tertulia y el estrado. [...] \\ $\mathrm{Y}$ aun, con todo, no me libro \\ de araños y abanicazos ${ }^{56}$.
}

El sainete nos dará a conocer algunos fragmentos del libro que les dedica, Observaciones de don Pedro Montefalco sobre el mérito de varias currutacas.

En otra obra, La casa de vecindad (primera parte), Andrés lleva la Ordenanza currutaca entre los papeles que vende y, algunas escenas después, cantará con otros ciegos:

$$
\begin{aligned}
& \text { Los señores currutacos } \\
& \text { solicitan que las damas, } \\
& \text { como ellos son machihembras, } \\
& \text { también sean marimachas. } \\
& \text { ¡Ay tira busín, } \\
& \text { ay tira busón! } \\
& \text { Señor currutaco, } \\
& \text { estire el calzón. } \\
& \text { Busín, busón, } \\
& \text { tire el calzón }{ }^{57} .
\end{aligned}
$$

La mención de "currutacas" y "currutacos" revela ciertos cambios, ya a fines del siglo, en las indumentarias de los usías en general, aunque el escarnio sea idéntico al que padecían los gurruminos y gurruminas. El vocablo "currutaco" debe ser, en mi opinión, anterior"s8 si bien René Andioc ha prestado su erudita atención al tema de la currutaquería en la últi-

${ }^{55}$ Según la clasificación temática de SALA VALLDAURA, J. M. Los sainetes de González del Castillo en el Cádiz de finales del siglo XVIII. Cádiz: Fundación Municipal de Cultura. Ayuntamiento de Cádiz, 1996, pp. 165-178.

${ }^{56}$ Obras completas, ed. cit., I p. 267.

57 Ibid., I pp. 155 y 162-163 respectivamente.

58 José Cadalso titula unas octavas «Un currutaco en 1770». En: CUETO, Leopoldo Augusto (ed.). Poetas líricos del siglo XVIII. Madrid: Atlas, 1952, I p. 267 b. BAE LXI. 
ma década de la centuria ${ }^{59}$, cuando comenta varias obras de aquellos años que atestiguan su abundante empleo; por ejemplo, el fin de fiesta Los currutacos del día, probablemente de 1798, que intenta beneficiarse del éxito de las cartas cruzadas entre Juan Antonio Zamácola, "Don Preciso", y "Don Currutaco" (quizás fray Juan Fernández de Rojas), en el Diario de Madrid, desde mayo de 1795. Los dibujos "Dandi-mono" y "La tortura del dandi", de Goya, ilustran algunos cambios indumentarios y hasta de pose por parte del nuevo petimetre:

\begin{abstract}
A López-Rey le llamaron ya la atención tres pormenores de la figura del petimetre: su corbata 'enorme', sus zapatos largos de punta corva y fina, y su fuerte bastón. Estos rasgos característicos permiten una segura identificación del tipo social representado por Goya, si se les agregan unos más, relativos a la indumentaria y peinado: los zapatos no llevan hebillas, sino lazos; las boquillas de los calzones no se ajustan debajo de la rodilla con jarretera ("charretera", solían decir entonces), sino también con lazos (son dos particularidades que se dan en varios elegantes de los Caprichos); las patillas son muy largas y pobladas, y el pelo, sobre todo, abundante, está dividido en mechones; la casaca, por su parte, lleva solapas grandes, como más claramente se ve en la variante ["La tortura del dandi"], en la que el elegante presenta los mismísimos rasgos distintitvos que se acaban de enumerar; y por fin, tampoco deja de ser llamativa la actitud o posición del personaje, con el pecho y el trasero sacados. Esta figura, en cierto modo nuevo avatar o retoño de la petimetría progresivamente asimilada por la literatura satírica, en particular el teatro breve, e incluso las artes gráficas, en la década de los noventa bajo el nombre de "currutaco" 60 .
\end{abstract}

La animalización de la figura del petimetre, llamado una vez más "mono", guarda absoluta equivalencia retórica y sinonimia relativa con el proceso de afeminarlo.

Por tanto, testigo de las novedades a la par que seguidor fiel de la tradición del género sainetesco, González del Castillo da un paso más en la evolución de un tipo que hará reír todavía bastantes décadas después, cuando compita como objeto de burla con los vestidos a la manera romántica. Se trata del petimetre o usía ahora llamado currutaco, término desconocido por el Diccionario de Autoridades, y personaje que da pie a renovar un tanto la risa con situaciones, gestos y palabras de gran ridiculez, ajustando la indumentaria y el peinado a la nueva moda. Así, en El robo de la pupila en la feria del Puerto, el autor gaditano se vale sobre todo del petimetre don Líquido y del abate don Estirado para sacar partido al menosprecio popular por tales esnobs, perfectamente adscribibles al currutaquismo. En efecto, el abate echa mano de su bastón y ambos podrían haber aparecido en escena contrahaciendo el gusto currutaco en boga, pues el gag de los bucles aclara la alusión a los tirabuzones de la letra de la canción antes citada y nos indica cómo llevan el cabello:

${ }^{59}$ Remito a «Goya y los temperamentos». Goya. Letra y figuras. Madrid: Casa de Velázquez, 2008, pp. 273-310.

${ }^{60}$ ANDIOC, R. ibid., pp. 275-276. 


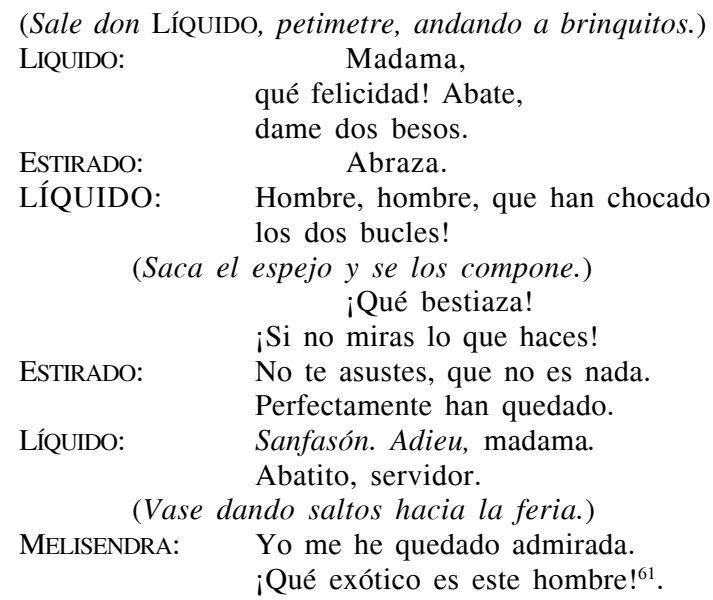

En cualquier caso, pocas escenas pueden resultar más claras en la ridiculización, sea de currutacos, sea de petimetres y abates: partiendo del código social que los juzga y los convierte en materia irrisoria, sus movimientos son impropios de dos hombres, y otro tanto los gestos y las palabras y las preocupaciones. Andar a saltos, abrazarse, besarse, arreglarse el pelo... La interpretación puede ser muy negativa, como la de Nicolás Gómez Ruiz y Ricardo Gómez de Ortega, quienes, desde parámetros más adecuados para la comedia de caracteres, acusan a González del Castillo de crear personajes muy simplistas ${ }^{62}$; y también puede ser positiva, al relacionar esta caricatura con la denuncia de los males sociales ${ }^{63}$ o con una cualidad artística, la de la expresividad dramática: «Castillo se sirve de la realidad para hacer teatro» ${ }^{64}$. Esta última afirmación queda avalada por las numerosas ocasiones en que el vehículo de la ridiculización no es únicamente verbal o factual, sino que se vale tanto de palabras como de hechos ${ }^{65}$.

${ }^{61}$ Obras completas, ed. cit., II pp. 310-311. (Corrijo el texto de Cano, según Romero Ferrer, A. y Sala Valldaura, J. M. (eds.). Sainetes escogidos. Sevilla: Fundación José Manuel Lara, 2008, pp. 422-423.

${ }_{62}$ «Juan Ignacio González del Castillo y el teatro popular español del siglo XVIII». Bulletin of Spanish Studies, 1924, I, pp. 135-140.

${ }^{63}$ FLECNIAKOSKA, Jean-Louis. «Un sainetero olvidado: Juan Ignacio González del Castillo». En: Actas del IV Congreso Internacional de Hispanistas. Salamanca, A.I.H. Consejo General de Castilla y León - Universidad de Salamanca, 1982, IV pp. 507-525.

${ }^{64}$ CALDERA, Ermanno. «La teatralidad de Juan Ignacio González del Castillo». En: ROMERO FERRER, A. (ed.). Juan Ignacio González del Castillo..., op. cit., pp. 101-116; la cita en p. 102.

${ }^{65}$ Véanse los comentarios sobre este tema de CHECA BELTRÁN, José. «Poética de la risa». Risas y sonrisas en el teatro de los siglos XVIII y XIX, Scriptura. 1999, 15, pp. 11-27, esp. pp. 20-23. 
El robo de la pupila en la feria del Puerto da lugar a estos comentarios, además de definir muy acertadamente las tareas de un abate ${ }^{66} \mathrm{y}$ de extraer un gran provecho cómico del viejo recurso de travestirse. Asimismo, González del Castillo aporta un ejemplo interesante de como la petimetría y el cortejo se asocian con la falta de virilidad porque sus representantes se alejaban de la rusticidad —es decir, la espontánea y bronca naturalidad - y del vigor del majismo: verbigracia, Don Jacobo comenta que «piensan las damas / que un hombre, para ser fino, / ha de estar hético ${ }^{67}$, adjetivo que se aplica a «cualquier cosa que está muy flaca y desmedrada», de acuerdo con Autoridades.

En Los literatos, la entrada a escena de don Juanito y otros currutacos para continuar las protestas contra el autor teatral, permite que éste se defienda del currutaquismo con estos versos:

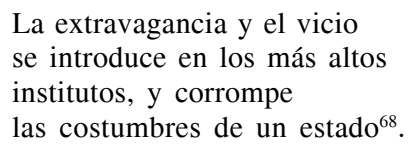

En otro lugar ${ }^{69}$, ya indiqué que la normalidad se fundamenta en González del Castillo alrededor de algunos conceptos conocidos por la codificación genérica, pero renovados. En gran medida, podrían servir para analizar las bases axiológicas de Ramón de la Cruz como continuador de los entremeses e iniciador de los sainetes. Recuerdo tales valores, a veces los amplío y añado otros dos:

a) la virilidad, que puede llegar a ser equivalente a la conducta considerada como tradicional española y que tiene como positiva hiperbolización la figura del majo (al que el espectador popular puede llegar a perdonarle su absoluta falta de afición al trabajo, contra todas las campañas ilustradas). El plebeyismo de las clases altas avala la virilidad como vitalismo, en oposición al afeminamiento petimetril. El afeminamiento es la traducción en el lenguaje del sainete de lo extranjero y nuevo, a partir de

${ }^{66}$ «ESTIRADO: Siembre he vivido entre damas. /Tocadores, gabinetes / y estrados fueron mis aulas. / He tenido conclusiones / amorosas, veces varias. / Y a fuerza de mis vigilias / y observativa constancia / en bailes, fiestas, teatros / y demás, tengo acabada / una obra de veinte tomos, / donde con razones claras, / y aun matemáticamente, / demuestro que las punzadas, / la jaqueca y otros males / y accidentes de las damas, / son efectos muchas veces/ de alguna amorosa causa. / [...] Mi profesión /es visitar dos mil casas, / ser en ellas confidente / general, andar en danza / sin pareja y, al instante / que el diablo tira la capa, / soy el primero que muda / temperamento» (Obras completas, ed. cit., II p. 309-310).

${ }^{67}$ La inocente Dorotea. Obras completas, ed. cit., I, p. 481.

${ }^{68}$ Los literatos, ibid., II, p. 49.

${ }^{69}$ «Los nuevos gustos en el teatro breve, a partir de los espacios de ficción y su teatralización en González del Castillo». En: ROMERO FERRER, A. (ed.). Juan Ignacio González del Castillo..., op. cit., pp.117-141, esp. pp. 138-141. 
una caricaturización negativa tan xenófoba como misoneísta. Fuera de la conducta viril, hay intereses económicos, pero no verdadero amor, el cual exige la llamada conducta tradicional española, garante del buen funcionamiento del matrimonio. El afeminamiento puede llevar a la animalización (recuérdense las monerías de su lenguaje gestual) y a la cosificación del petimetre, calificado en ocasiones de "mueble" o "muñeco".

b) la autoridad, que es consecuencia de la virilidad y que es también necesaria para que el marido pueda frenar las "naturales" inclinaciones de la esposa al despilfarro, la ociosidad, la coquetería, etc. Debido a razones morales, fomentadas sin duda por la política ilustrada, los sainetes del autor gaditano acogen con mayor frecuencia la carencia de autoridad en el marido de clase alta y en el cortejo, redimido aquél y castigado éste mediante el regreso a la normalidad moral del desenlace. «Pongamos remedio; honor, / aunque algo tarde», como concluye el esposo Policarpo en La mujer corregida y marido desengañado ${ }^{70}$.

c) la sinceridad, que descalifica los excesos de los tunos y fanfarrones o la hipocresía de las "beatas", pero, sobre todo, las falsas pretensiones de transclasamiento de las majas que aceptan cortejo, las ambiciones nobiliarias sin fundamento y la costumbre del cortejo en todas sus manifestaciones.

d) la religiosidad, casi siempre ausente: cumple un papel secundario pues su falta acompaña al afeminamiento en el caso del abate — petimetre de segunda, condenado a fracasar en cualquier tentativa sentimental- . Al ser extranjerizantes, tanto el abate como el petimetre y la petimetra descuidan sus obligaciones religiosas. La religiosidad se equipara con otras cualidades propias de la moral tradicional española, las que garantizan una buena esposa y una correcta educación de los hijos.

e) la cultura, que tiene relevancia significativa en el caso del abate, paralelamente a la religiosidad. Por tanto actúa jocosamente a contrario, desde la ostentación de la ignorancia, por pedantería. Al igual que en la religiosidad, su falta contribuye en grado menor a la caracterización negativa del petimetre. En cambio, el soldado fanfarrón o el majo tuno suplen, al menos en parte, su incultura merced al gracejo verbal.

f) la civilidad, que es urbana tanto en su manifestación positiva (el conocimiento del código social imperante, la comprensión de los estímulos verbales y extraverbales) como en su manifestación negativa (la ridícula entronización de la moda). La ignorancia animaliza al payo, tildado de "burro" o comparado con él, por desconocer los códigos urbanos (particularmente el de la moda, en el caso del hidalgo de lugar) y malinterpretarlos desde la literalidad, mientras la petimetría prolonga el tópico de la corrupción como propia de la ciudad.

Algunas dualidades del género entremesil quedan, por tanto, alteradas:

${ }^{70}$ Obras completas, ed. cit., II p. 214. 
1) la del viejo y el joven, que opera en menos ocasiones porque la acción se dirime bastante más a menudo, en los sainetes dieciochescos, dentro del matrimonio, con la amenaza del adulterio (por causa del consumismo), frente al tradicional triángulo entre mujer casadera, viejo rico y joven enamorado;

2) la de la mujer y el marido, mediante la presencia actualizadora del cortejo, que matiza el viejo tipo del cornudo y elimina la uxor dotata; y

3) la del rico y el pobre, en la medida en que se asocia con frecuencia lo uno con la petimetría y lo otro con el majismo. La novedad del plebeyismo invierte la mímesis social y ratifica la alegría de vivir popular.

Además, los conceptos del "honor" y la "dignidad" de origen caballeresco, tan operativos en el teatro áureo, se han deslizado (y desemantizado) camino de la jactancia y el despejo, mientras que, a su vez, la teatralización del noble es siempre ridiculizadora y jocosa por ser falsa.

\section{Algunas CONCLUSIONES Y PROYECCIONES}

Socialmente, hay que entender la crítica a la petimetría desde una axiología que sostiene hasta el extremo la "normalidad" moral de la discreción de la mujer, cuyo recato se desea preservar, con todo lo que esto representa, antes del matrimonio y durante el matrimonio. Teatralmente, tal crítica sirve para alabar, por contraste o por plebeyismo, el modelo caballeresco español, de manera que los usías son enfrentados a los majos e, incluso, a los payos, a favor del modo más popular y nacional de entender la vida. La evaluación moral de los majos tunos, pícaros, fanfarrones, etc. no es tan negativa como la que sufren madamas y pisaverdes. De esta manera, la petimetría se encuentra relacionada semánticamente con el afeninamiento, condenable por venir del extranjero, en contraposición con el majismo español, de raigambre popular y hasta de procedencia aristocrática: «Así se puede producir la imitación de comportamientos nobiliarios que han quedado vacíos, en la gesticulación del majo, atrevida, ostentosa y desafiante, tres adjetivos de procedencia caballeresca» ${ }^{71}$. Si acaso, como ya mencionábamos, la hiperteatralización majista conduce a una falsa virilidad, la de los fanfarrones y bravucones que simulan valentía, porque "valentía" y "virilidad" forman parte de la misma área conceptual. A pesar de todo, el majo tuno o crúo jamás podrá ser calificado de afeminado, porque esto último se asocia a lo nuevo y poco castizo, a lo extranjero y poco español... y, en cambio, la majeza a la virilidad. En palabras de José

${ }^{71}$ MARAVALL, J. A. «La época de Goya». En: IGLESIAS, M.C, (ed.)Estudios de la historia del pensamiento español (siglo XVIII). Madrid: Mondadori, 1991, pp. 100-112; la cita en p. 110. 
María Rodríguez Méndez referidas a los manolos de los escenarios y los barrios populares: «Y nada más patente y primordial en el hombre que la manifestación de sus instintos vitales, entre los que cuenta el sexo como fundamental» ${ }^{72}$.

Por el contrario, sobre la base de una moral conservadora, a los petimetres se les llega a denominar por su enfermedad o locura, por su falta de valentía y rudeza, "hombri-mujeres", entregados «a la delicadeza, al lujo y a la afeminación»:

Pretendo sólo manifestar lo grave de la enfermedad por los daños que causa a la naturaleza. Y digo bien a la naturaleza, pues parece que está avergonzada de mirar cada día más y más burlados sus intentos y despreciados sus esfuerzos en producir hombres, hombres, y que se entretiene en franquearnos muñecos, que lejos de cumplir con la obligación de su valiente sexo, sólo piensan en ser hombrimujeres, adulterando con afeminación lo majestuoso, lo respetable y lo venerable de su hermosura.

[...] Esta vergonzosa afeminación hace a los hombres cobardes, ignorantes y descuidados de sus obligaciones ${ }^{73}$.

(Un proceso parecido, aunque menos degradante, llevaba a los abates pedantes a ser denominados "eruditos a la violeta" o "semisabios".) Entre esos descuidos de sus obligaciones denunciados por La Pensadora Gadita$n a$, figura que los esposos permitan a sus mujeres el recibir cortejos y salir con ellos. Por su falta de autoridad, el marido consentidor recibe el secular varapalo, ahora con la fuerza añadida de la distinción entre la majeza (Basilia) y la petimetría (don Lamberto):

\begin{tabular}{ll} 
BASILIA: & $\begin{array}{l}\text { Un marido sin aliento } \\
\text { para, de una vez, dejarla } \\
\text { despachurrada. }\end{array}$ \\
LAMBERTO. & \multicolumn{1}{c}{ Eso es bueno } \\
& $\begin{array}{l}\text { para la gente ordinaria, } \\
\text { También aquellos son hombres } \\
\text { BASILIA. }\end{array}$ \\
$\begin{array}{l}\text { y los demás son muñecos, } \\
\text { pues saben enderezarnos } \\
\text { cada vez que nos torcemos }\end{array}$
\end{tabular}

En suma, son varias las concausas que se encadenan para explicar en buena medida la existencia y la evolución de los elegantes desde Antonio

\footnotetext{
72 Ensayo sobre el machismo español. Barcelona: Península, 1971, p. 84.

${ }^{73}$ La Pensadora Gaditana. Canterla, C. (ed.). Cádiz: Universidad de Cádiz, 1996, I pensamiento iii, pp. 61-73; las citas en pp. 65 y 71. (La cursiva es del texto original).

74 VÁZQUEZ, Sebastián. El marido desengañado (1792), aunque hasta ahora se había publicado como de J. I. González del Castillo. Obras completas, ed. cit., II p. 156; así lo demuestra PEYTAVY, Christian. Les sainetes de Sebastián Vázquez: entre tradition et modernité (1773-1793). Pau: Université de Pau et des Pays de l'Adour, 2006, 3 vols. tesis inédita.
} 
de Zamora a Juan Ignacio González del Castillo. Podemos verificarlas a partir de la tradición teatral (los lindos, los intermedios, etc.), la literatura coetánea (el periodismo, la poesía satírica, el ensayo moral), el testimonio de los viajeros y los fenómenos sociales y literarios europeos equivalentes. También conviene agregar otro motivo menos detectable a primera vista, ya que exige cierta capacidad inductiva: los usías caricaturizados por el teatro breve setecentista asumen defectos del marido entremesil, porque el paradigma moral desde el que se les juzga alcanza la unanimidad de conservadores e ilustrados en la condena ética y económica del cortejo y en la defensa del matrimonio. El rechazo de casi todos se desplaza contra el tercero en discordia del triángulo, el que tiene un papel extramatrimonial y quizás adulterino, sin que el público y, por tanto, los códigos redundantes del género sainetesco alcancen a ver la incipiente necesidad de independencia de la mujer, la importancia del consumo para el progreso, los nuevos ámbitos de actividad intelectual de los literatos (en este caso, abates), la secularización de la sociedad o los beneficios culturales del nuevo ocio.

El rehúso de lo extranjero y lo nuevo se simboliza metonímicamente en la indumentaria y la música por su rotundidad y eficacia escénicas, pero también en el peinado, la gesticulación y el lenguaje. Reforzándose mutuamente, la majeza castiza y tradicional se contrapone a la petimetría, y en la bipolaridad consecuente, lo que en aquélla es virilidad, pasión y alegría de vivir, sinceridad o valentía es en ésta lo contrario: afeminamiento, afectación e imposibilidad de sentimientos, falta de autoridad, cobardía...

Acerca del éxito como objetos jocosos de los petimetres, abates, etc., puede también argüirse otra explicación diegética y estructural que no cabe argumentar mediante ejemplos incontrovertibles: el desarrollo sintáctico y argumental del sainete, que llega a doblar y a triplicar la extensión del entremés barroco, favoreció no sólo la especialización (la de los graciosos), sino también la intensificación dialéctica de oposiciones caricaturescas entre protagonistas y antagonistas. El acercamiento a la realidad desde la voluntad neoclásica hizo el resto, aunque no quepa hablar, a propósito de este teatro breve, de pintura realista, sino de caricatura de la cotidianidad y de la intimidad.

Por todo lo cual, ¿resulta factible englobar gurruminos, petimetres, abates y currutacos bajo un solo concepto unificador y suficientemente general?, ¿el de "usías", por ejemplo, de querer valerse de un vocablo coetáneo?, ¿o el de elegantes? Presentan sin duda características en común, basadas en una comparable transgresión de la normalidad sociomoral: así, ninguno de los cuatro respeta los códigos del matrimonio fijados por la tradición (la autoridad del marido, la discreción de la esposa, la intimidad de la casa), y todos se apartan de lo que se considera el comportamiento viril con sus gestos, lenguaje, indumentaria, temas de conversación, etc.

Sin embargo, cualquier concepto aglutinador, más o menos paralelo al 
de "petimetría", no tomaría en cuenta diferencias fundamentales respecto al matrimonio como motivo argumental y eje moral. El gurrumino está casado; el petimetre puede estarlo o no, aunque corteja a quien no es su esposa; y el abate es célibe. Profesionalmente, el abate sirve para ridiculizar al hombre de letras mundano y, si llegamos a saber en qué debería ocuparse, averiguamos que trabaja para alguna familia adinerada como maestro de música o de gramática, o bien como administrador; jamás sufraga los caprichos y gastos económicos de las damas, lo que sí hacen algunos petimetres, cuyo nivel económico es, o aparenta ser, superior. Por lo que atañe a los gurruminos, ni siquiera resulta necesario que residan en la ciudad, y, por tanto, impiden establecer como elemento común la condición urbana del arquetipo, por más que éste sirva para caricaturizar conductas y mentalidades propias de Madrid, Cádiz, etc.

¿Existe una evolución que permita al menos una clasificación cronológica? El gurrumino precede al petimetre y hasta al abate, que en la última parte del siglo comparten defectos y burlas con el currutaco. Esta última palabra a menudo no es más que un sinónimo finisecular de "petimetre", pero anuncia ya alguna variante en el desarrollo de la persona y el personaje. Según parece por la literatura, las ilustraciones, etc., se habría producido en los últimos años del Dieciocho un cierto desgaste en las reconvenciones morales contra el cortejo, lo que favorecía que el periodismo costumbrista enfatizara casi únicamente su esencial condición de personaje estrambótico. La centuria ha recorrido bastante distancia, si tomamos como punto de partida la defensa moral de la autoridad del esposo cuando se condenaban las flaquezas de los gurruminos de las primeras décadas. El papel importantísimo del dinero, el lujo, la moda, el ocio en las obras de Cruz o de González del Castillo revelarán que el ethos burgués empieza a imperar en los paradigmas del deseo y de la realidad sociales.

En los sainetes de la segunda mitad del siglo XVIII, leemos el envés de un cambio de mentalidad, la cara opuesta de la liberación e individualización de las conductas. En algunos sectores tanto populares como más acomodados económicamente, una cierta asunción del cuerpo se liga a una incipiente asunción de la alegría de vivir y a una sociabilidad más abierta que irá materializando, sobre todo en el siglo XIX, el espíritu burgués: el consumo de modas, la cultura del ocio, los nuevos espacios públicos de la mujer. De esta manera, para el historiador, los cuerpos de gurruminos, petimetres, abates y currutacos han adquirido un valor simbólico y metonímico que ayuda a entender la pugna moral entre el tradicionalismo y la modernidad, la virulencia con que aquél atacó a ésta.

Fecha de recepción: 25 de junio de 2008

Fecha de aceptación: 10 de marzo de 2009

RLit, 2009, julio-diciembre, vol. LXXI, n. ${ }^{\circ}$ 142, 429-460, ISSN: 0034-849X 